Journal of Animal and Veterinary Advances 11 (14): 2493-2502, 2012

ISSN: $1680-5593$

(C) Medwell Journals, 2012

\title{
POMA-BROILER: A Computer Simulation Model to Evaluate the Optimal Market Age of Broilers
}

\author{
${ }^{1,3}$ B. Y. Wang, ${ }^{2}$ L.H. Chien and ${ }^{3}$ S.W. Roan \\ ${ }^{1}$ Livestock Management Division, Livestock Research Institute, Council of Agriculture, \\ Mu-Chung Road, Hsinhua, 71246 Tainan, Taiwan \\ ${ }^{2}$ Department of Applied Economics, ${ }^{3}$ Department of Animal Science, \\ National Chung Hsing University, 250 Kuo Kuang Road, 40227 Taichung, Taiwan
}

\begin{abstract}
This study presents the POMA-BROILER Model, a computer simulation developed to evaluate the optimal market age of broilers. This model was written in the Visual BASIC programming language and uses the windows operating system. The model was developed from a Sensitivity Analysis Method and is based on the concept that marginal cost must not exceed marginal return. It uses various input data including feed information (Crude Protein (CP), Metabolisable Energy (ME) and feeding stages) an equation for the feed conversion ratio, cost conditions (chicks, feed, labour, water and power, medical treatment, depreciation and miscellaneous costs) and a growth regression equation. The model then compares the calculated results with the range for acceptable market weight. The marginal cost and marginal return are calculated every day to determine the decision-making point for maximum profit. These results could represent a valuable reference for use in adjusting the strategy for broiler production and management.
\end{abstract}

Key words: Broiler, market age, Simulation Model, production, management, profit

\section{INTRODUCTION}

According to the Taiwan Agricultural Yearbook (COA, 2010), Taiwan located in a subtropical area, produced 501,607, 524,059 and 527,906 tons of broiler carcasses, representing $8.94,8.98$ and $8.38 \%$ of the total agricultural product value in the years 2008, 2009 and 2010 , respectively. Broiler production is the second most valuable livestock industry in Taiwan. Its value is only slightly less than that of the pork industry.

The accuracy and utility of growth models has improved with the ability of modern computers to perform complex calculations rapidly. Researchers have attempted to use a Simulation Model to predict broiler growth and production. Velu et al. (1972) proposed a set of regression equations for determining the body composition of young chicks. Emmans (1981a, b) considered genetic condition, ration components, management decisions and environmental factors to build a Poultry Growth Model (PGM) that could predict poultry growth and carcass component changes on a daily basis. Talpaz et al. (1986) proposed a Dynamic Optimisation Model for the feeding of broilers. Muramatsu and Isariyodom (1989) established a computer Simulation Growth Model to predict the need for replacement pullets with special reference to seasonal changes in feed intake. Supaporn et al. (1988) and Grosskopf and Matthaus (1990) introduced a Mathematical Simulation Model for broiler production processes separately. Burlacu et al. (1990) built a mathematical model for energy and protein balance simulation in broilers. Wolynetz and Sibbald (1986a-c, 1990) introduced several methods to predict the major body components of broiler chickens. Emmans (1995) considered several variables relating to feed, environment and management as a basis for the prediction of broiler growth. Wang et al. (1995) and Roan and Wang (1996) adopted concepts from Leeson and Summers (1980), Emmans (1981a, b), Zoons et al. (1991) and Roan (1991) to construct a computer simulation model to predict broiler growth in Taiwan. Lee et al. (1997) presented a study to determine the optimal market weekly age of Taiwan country chickens. Roush et al. (2006) compared the Gompertz and Neural Models of broiler growth with neural networks. Ahmad (2009) compared the Gompertz Model, Nonlinear Statistical Model and Neural Network Model of poultry growth.

Corresponding Author: S.W. Roan, Department of Animal Science, National Chung Hsing University, 250 Kuo Kuang Road, 40227 Taichung, Taiwan 
Broilers should be sold at an optimal weight. More profit can be achieved if broilers can be sold at an optimal market age and meet consumer preferences and market needs. Because of the fast growth of broilers and the Electro-Slaughter System, the standardisation of broiler production is increasingly important.

If the optimal market age of broilers can be accurately predicted, the operating profits can be increased. Maximum return is always a farmer's production target. The purpose of this study was to build a Simulation Model to evaluate the optimal market age of broilers based on the concept that the marginal costs must not exceed the marginal return.

\section{MATERIALS AND METHODS}

The model was written in the Visual BASIC computer programming language and uses the Windows operating system. Seven functions were considered: base, cost, growth function, Feed Conversion Ratio (FCR), market, calculation and analysis with a page dedicated to each function. Each page contained several input items and choices as shown in Fig. 1.

System of functions: The default feed conversion ratio and growth regression equation were taken from the results of $\mathrm{Hu}$ (1995) and Roan and $\mathrm{Hu}$ (1996):

$$
\begin{aligned}
\text { Cock, FCR } & =0.848+0.000954 \mathrm{~W} \\
\text { Hen, FCR } & =0.933+0.00103 \mathrm{~W}
\end{aligned}
$$

$$
\begin{aligned}
\text { Cock, } \mathrm{W}= & 4567.5+49.564 \text { day }^{-} 0.094 \text { day }^{2}-65.075 \\
& (\mathrm{ME} / \mathrm{CP})+0.215(\mathrm{ME} / \mathrm{CP})^{2} \\
\text { Hen, } \mathrm{W}= & -525.92+32.599 \text { day }+0.22(\mathrm{ME} / \mathrm{CP})^{2}
\end{aligned}
$$

Where:

FCR $=$ The feed conversion ratio

$\mathrm{W} \quad=$ Body weight $(\mathrm{g})$

Day $\quad=$ The daily age

$\mathrm{ME} / \mathrm{CP}=$ The ratio of metabolisable energy to crude protein in the feed

Users can also set individual parameters to create new calculation functions to meet their particular needs.

Concepts: The algorithm for this model finds a break-even point to attain the economic regulation of maximum profit so that Marginal Cost (MC) equals Marginal Return (MR). If this break-even point lies within the acceptable market range for weight then this point is the optimal result (Fig. 2a).

If this break-even point is higher than the maximum weight in the acceptable market range for weight, the chickens can only be raised until they reach the maximum weight (Fig. 2b). If this break-even point is lower than the minimum weight in the acceptable market range for weight, the farmer still needs to raise the chickens until they reach the minimum weight (Fig. 2c). The optimal market age is therefore derived according to the optimal result.

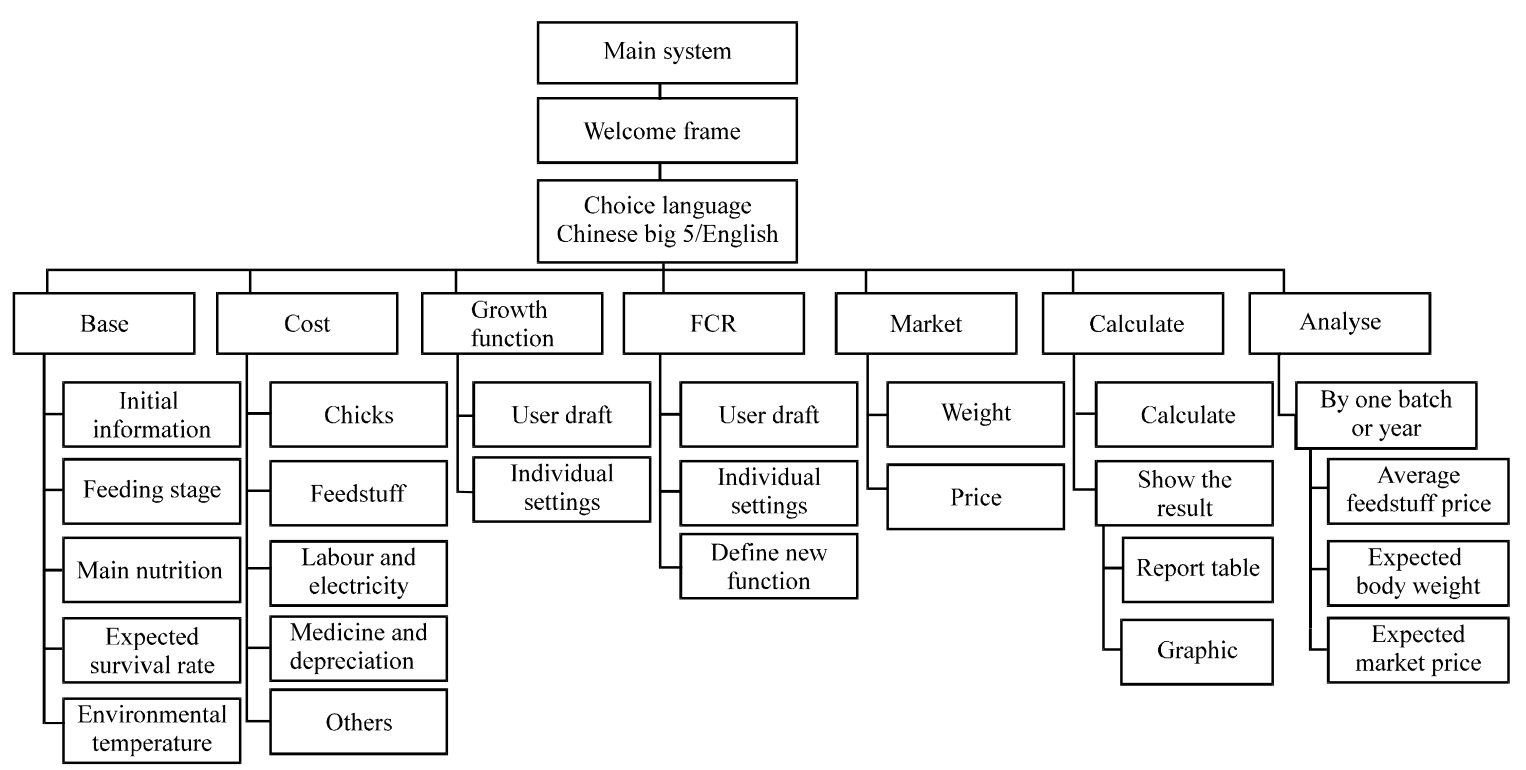

Fig. 1: Framework of the simulation model for predicting the optimal market age of broilers 

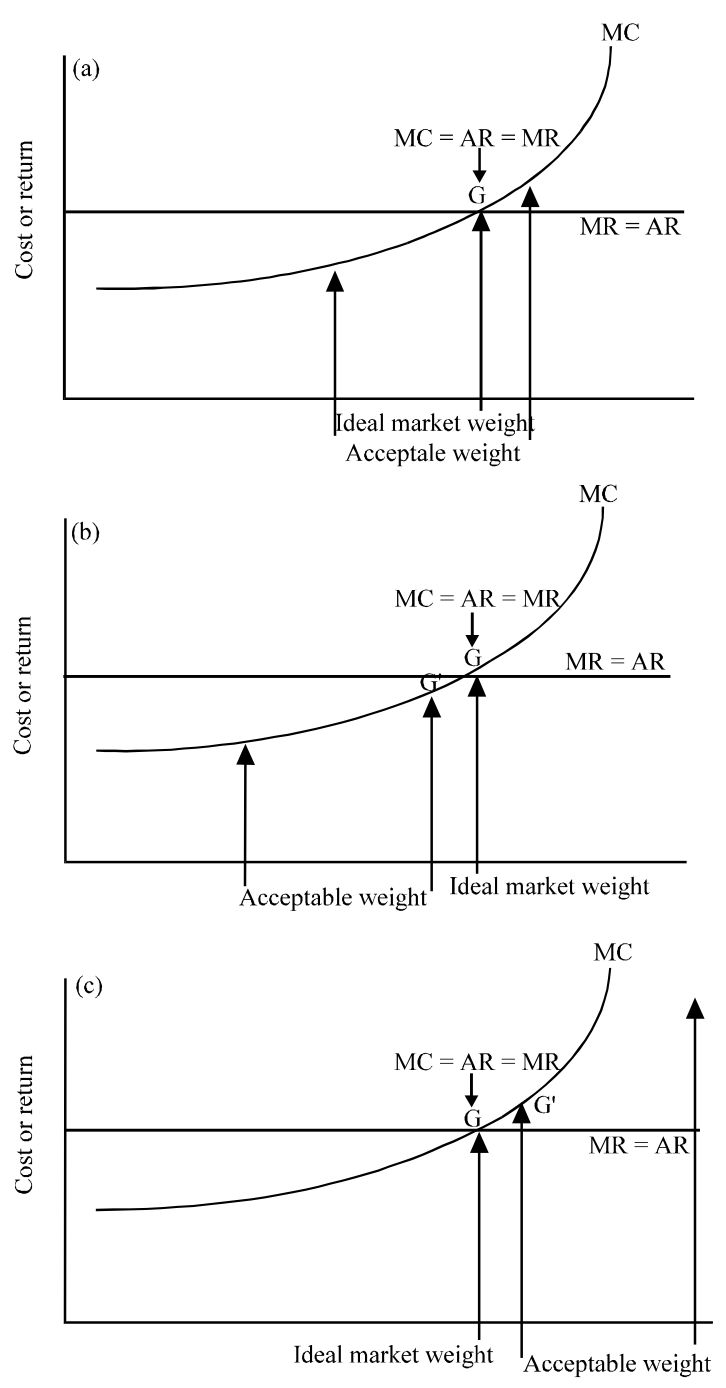

Fig. 2: Determination of the break-even point $(\mathrm{G})$ to find the optimal market weight of chickens. (MC: Marginal Cost; AR: Average Return; MR: Marginal Return)

\section{RESULTS AND DISCUSSION}

\section{System description}

Base: This page includes initial weight (g), stage by weekly age, daily age or body weight. Users can select one or two stages to change feed and can set the start point, crude protein (\%), metabolisable energy $\left(\mathrm{kcal} \mathrm{kg}^{-1}\right)$, expected survival rate $(\%)$ and environmental temperature $\left({ }^{\circ} \mathrm{C}\right)$ for this option.

Cost: This page includes chicks, feed, labour, electricity, medicine, depreciation and other costs.

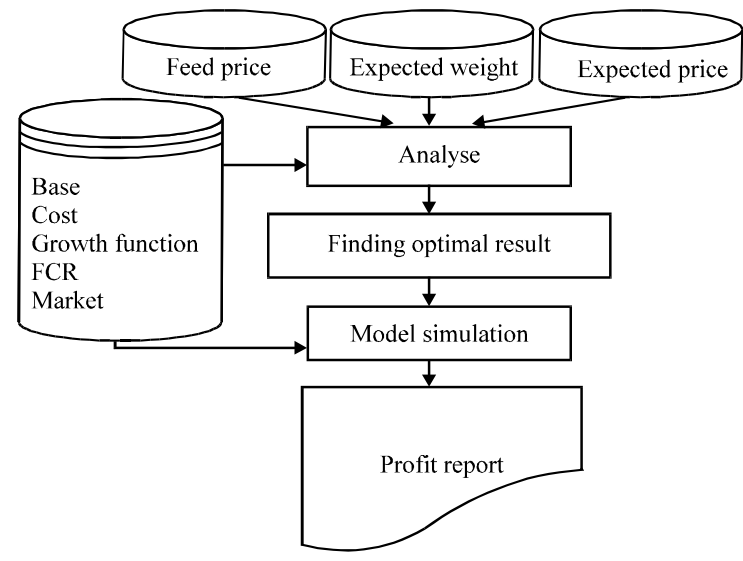

Fig. 3: Framework for the analysis function

Feed conversion ratio: This page includes three parts of the default function, individual settings or a user's own regression equation.

Market: This page includes the ranges of market weight $(\mathrm{g})$ and price (NT\$).

Calculation: This page includes the calculated results and displays the results graphically. These reports contain the optimal market age (days), market weight (g), Average Daily Gain (ADG, g), Feed Conversion Ratio (FCR), total feed intake (tons), total feed cost (NT\$), total cost (NT\$) and net income (NT\$/bird).

Analysis: This page analyses the optimal profit for one batch or 1 year. It can also analyse the optimal result based on the average feed price, expected body weight (g) or expected market price (NT\$) (Fig. 3) and the codes for the predicted optimal market age of broilers (Table 1) and the codes for the sensitivity analysis (Table 2).

\section{Calculation example}

Input base data: This example sets the initial body weight to $56 \mathrm{~g}$ and includes 2 stages of change in the weekly feed rations. The first stage starts in the 1st week with $23 \%$ crude protein and $3,200 \mathrm{kcal} \mathrm{kg}^{-1}$ of metabolisable energy. The second stage starts in the 3rd week with $20 \%$ crude protein and $3,200 \mathrm{kcal} \mathrm{kg}^{-1}$ of metabolisable energy. The expected survival ratio is $95 \%$ and the environmental temperature is $25^{\circ} \mathrm{C}$ (Fig. 4).

Input cost data: The example assumes that 50,000 birds are raised at a cost of $15 \mathrm{NT} \$ /$ bird. The resulting total chick cost is 750,000 NT\$. The feed costs in the first and second stages are 11.4 and $10.5 \mathrm{NT} \$ \mathrm{~kg}^{-1}$, respectively. The following costs were defined: labour, 25,000 NT\$/month; 
Table 1: The code for the predicted optimal market age of broilers

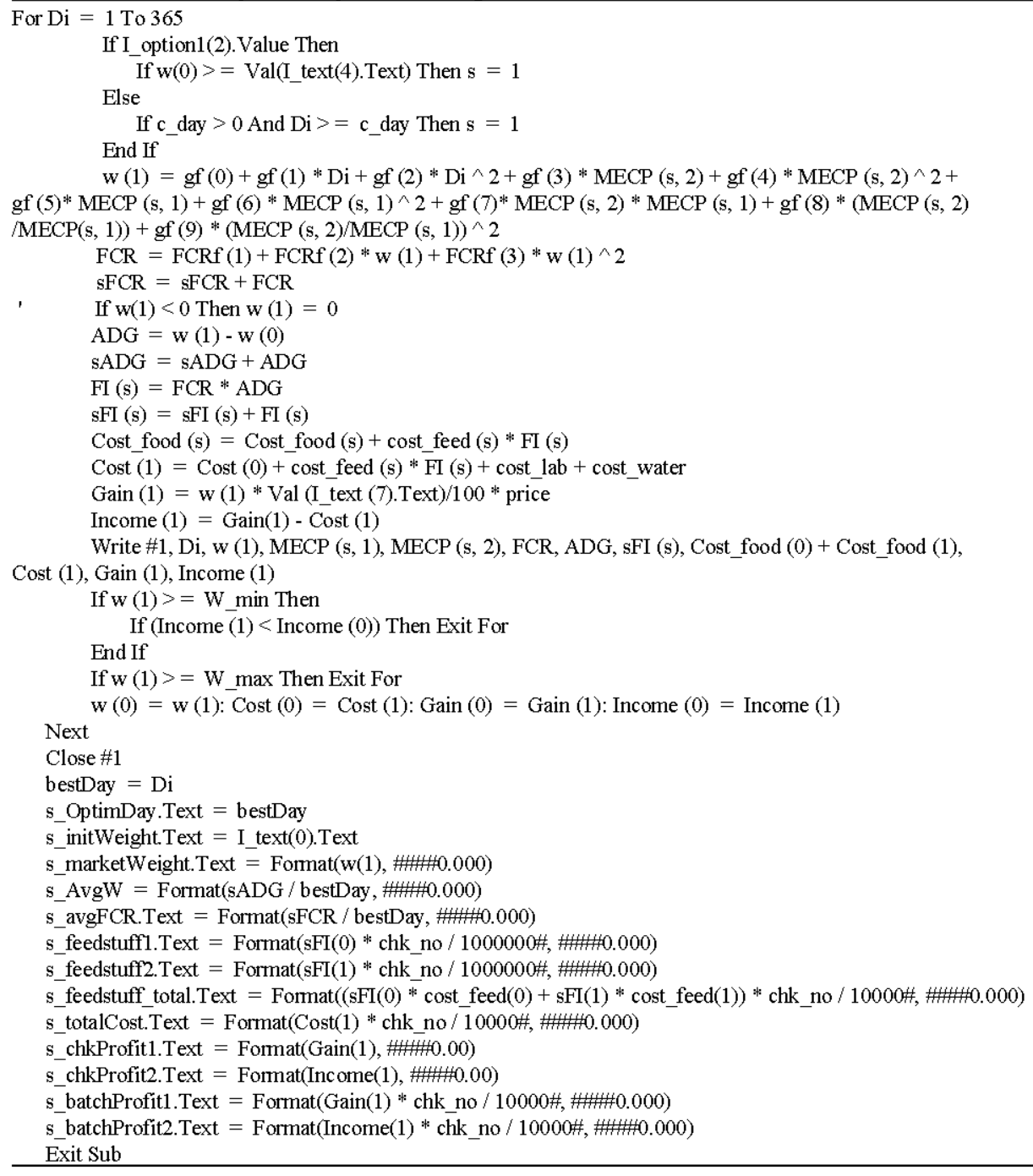

Table 2: The code for the sensitivity analysis

Dim cost_food_max (1) As Double, cost_food_min (1) As Double, step 1 As Integer, step 2 As Integer

Dim k As Integer, FI (1) As Double 
Table 2: Continue

Cost_food $(1)=$ cost_food_min $(1)+(j-1) *($ cost_food_max $(1)-$ cost_food_min $(1)) /(\operatorname{step} 2-1)$
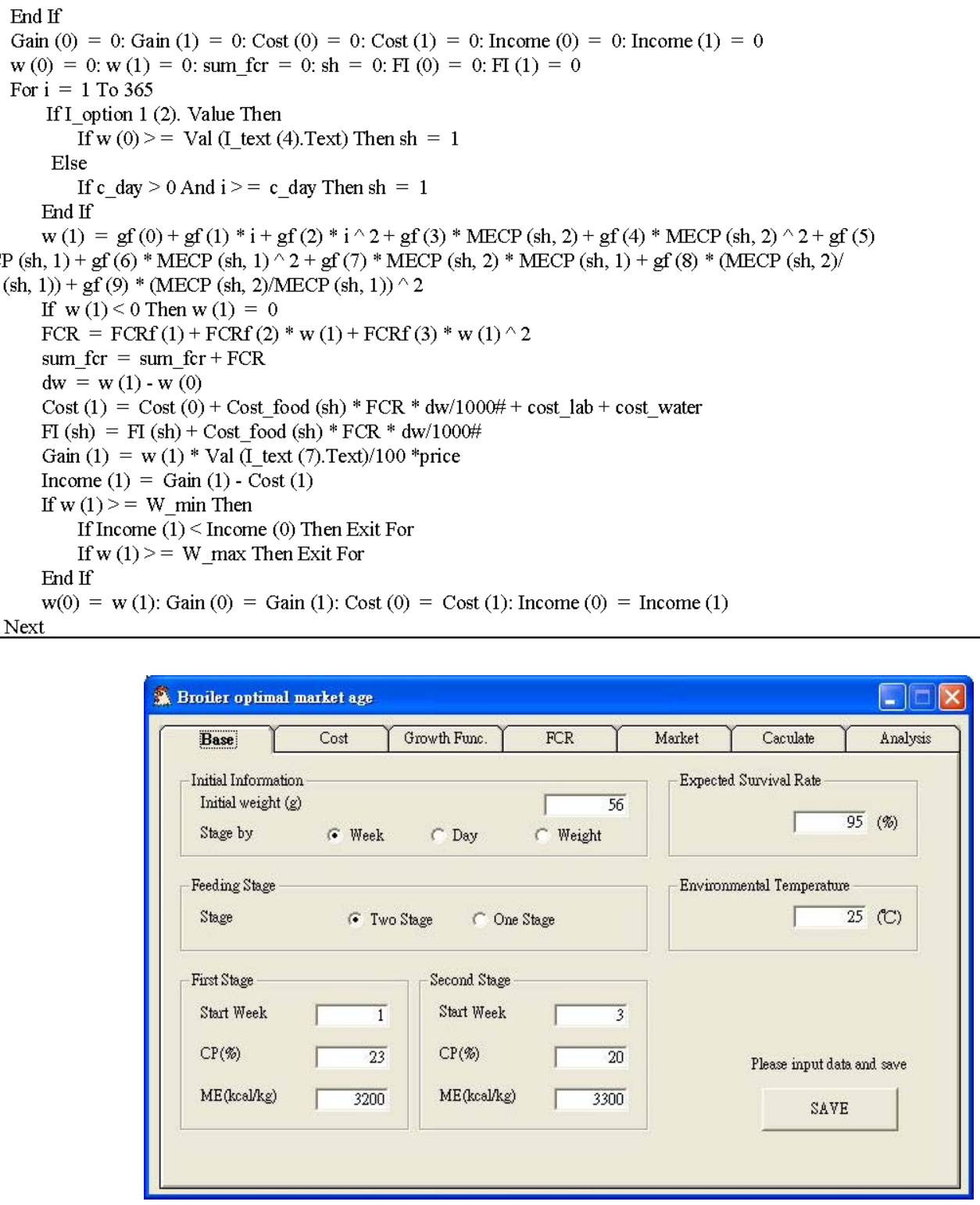

Fig. 4: The base page for the POMA-BROILER System

electricity, 2,200 NT\$/month; medicine, 4 NT\$/bird; depreciation, $3.5 \mathrm{NT} \$ /$ bird and other costs, $5 \mathrm{NT} \$ /$ bird (Fig. 5).

Growth function: The default growth regression equation for cocks was selected in this example (Fig. 6).

Feed conversion ratio function: This example selected the default FCR function for cocks (Fig. 7). Acceptable range for market weight: The acceptable range for market weight was set to $1,600-2,200 \mathrm{~g}$ and the market price was 60 NT\$ $\mathrm{kg}^{-1}$. All these data were stored and used for calculation by the model (Fig. 8).

Calculation: A result is presented immediately after the calculate button is pressed. This example demonstrates that the optimal market age is 56 days with a market weight of $2,164.30 \mathrm{~g}$, an ADG of $38.65 \mathrm{~g}$ and an FCR of 1.80. The feed intake is 36.81 tons for the first stage and 169.0 tons for the second stage. The total feed 
J. Anim. Vet. Adv., 11 (14): 2493-2502, 2012

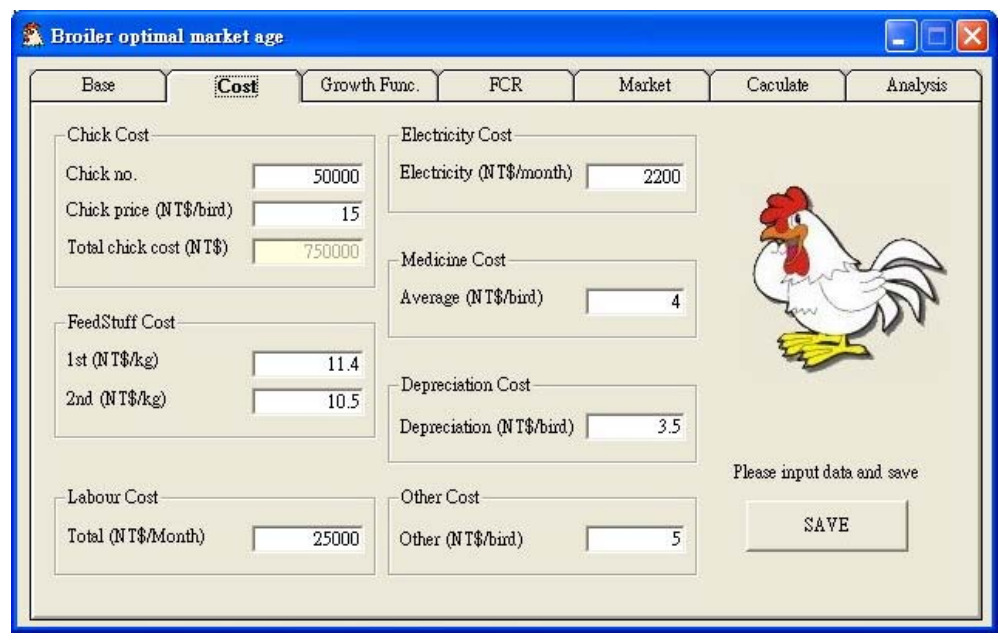

Fig. 5: The cost page for the POMA-BROILER System

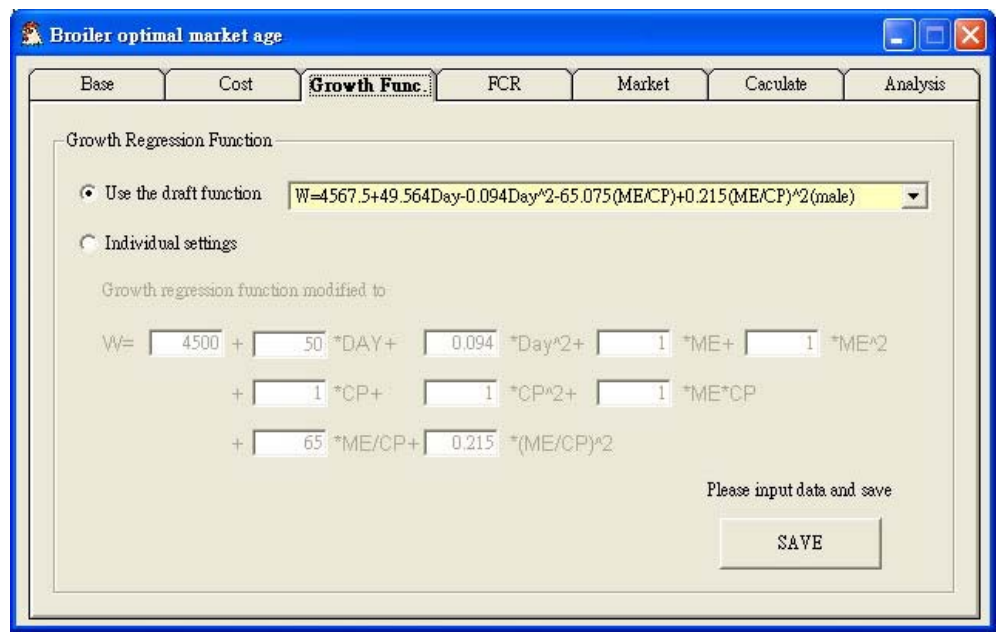

Fig. 6: The growth function page for the POMA-BROILER System

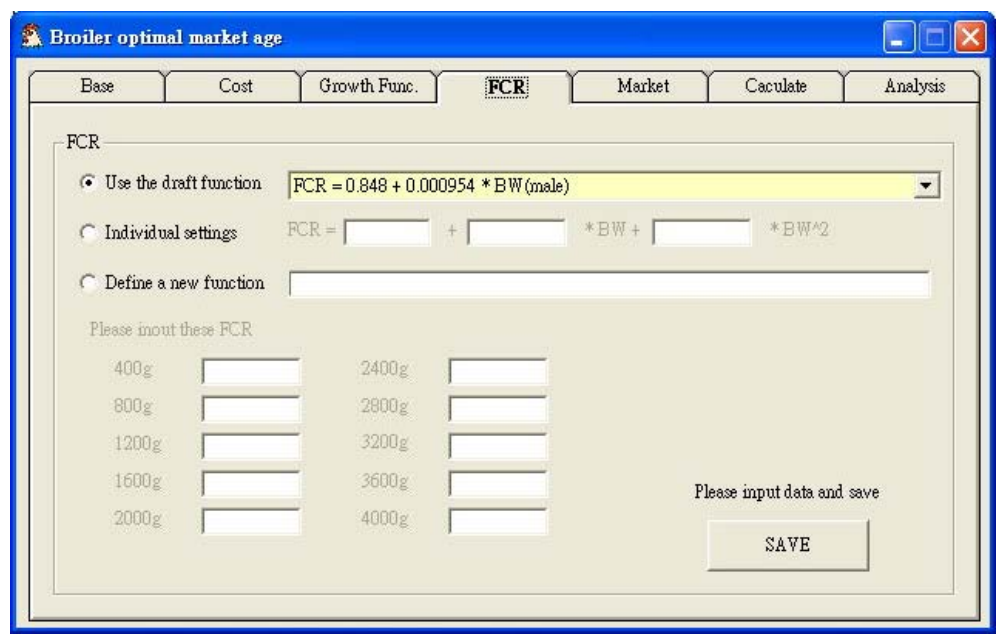

Fig. 7: The FCR page for the POMA-BROILER System 
cost is 2,193,450 NT\$ and the total cost is $3,619,220 \mathrm{NT} \$$. The gross profit is $123.37 \mathrm{NT} \$ /$ bird with a net profit of $50.98 \mathrm{NT} \$ /$ bird, a batch gross profit of $6,168,260 \mathrm{NT} \$$ /batch and a batch net profit of $2,549,030 \mathrm{NT} \$$ /batch (Fig. 9). The program also displays these results in both table and graph formats.

Analysis: This example selects the optimal annual profit for 1 year and selects the average feed price as the decision point. The price of the two feeds was set to 10-15 NT\$ $\mathrm{kg}^{-1}$ and a change including five steps was also chosen (Fig. 10). The optimal profit for each combination was accordingly derived (Fig. 11). The predicted results were compared with the recommended NRC (1994) value. Researchers set the growth function and FCR function ourselves according to the following equations:

$$
\begin{gathered}
\mathrm{W}=4755.5+30.932 \text { day }+0.4898 \text { day }^{2}-65.075 \\
(\mathrm{ME} / \mathrm{CP})+0.215(\mathrm{ME} / \mathrm{CP})^{2} \\
\mathrm{FCR}=0.98+0.00063 \mathrm{~W}
\end{gathered}
$$

The comparison shows that the trends for body weight change are quite similar (Fig. 12) and that the trends for changes in feed intake ( $\mathrm{g} /$ week) are close (Fig. 13). Many factors affect the cost of production and net profit per broiler. However, broiler profit is significantly affected by market weight and market price. Research by Farooq et al. (2001) indicated that the market age has a negative effect $(p<0.01)$ on the net profit per broiler but no effect on the cost of production. The reduced net profit per broiler at increased market age could be a result of a poorer FCR and extra management costs due to the prolonged rearing period. The results

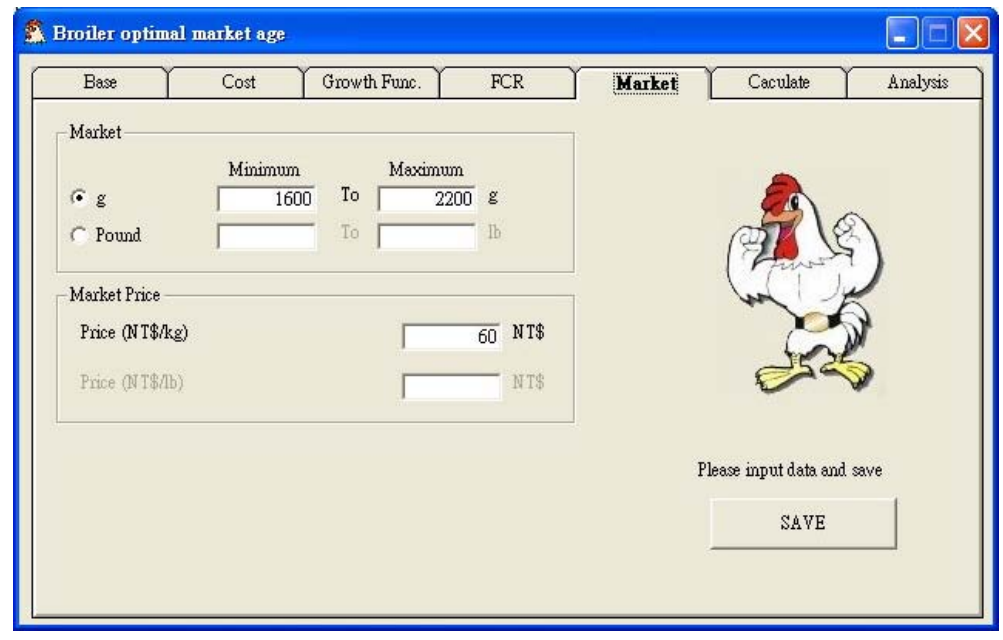

Fig. 8: The market condition page for the POMA-BROILER System

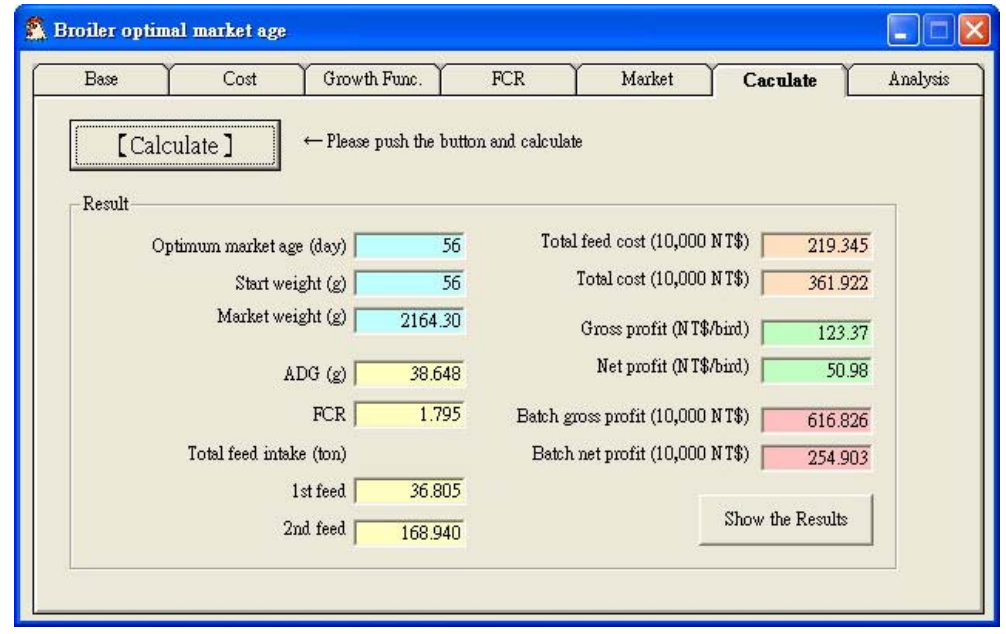

Fig. 9: The results calculation page for the POMA-BROILER System 


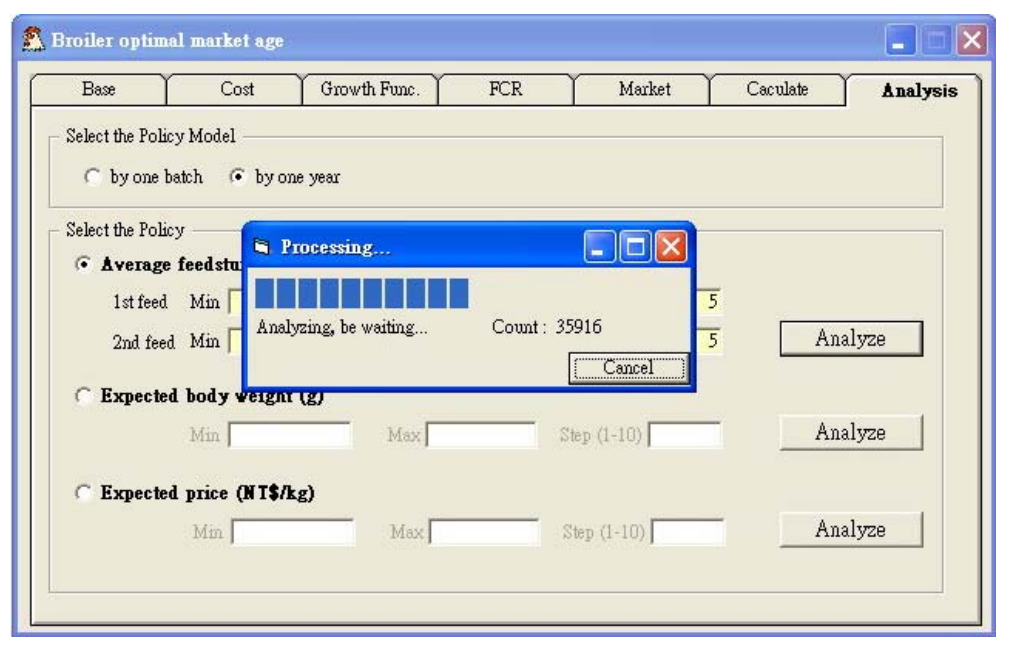

Fig. 10: The sensitivity analysis page for the POMA-BROILER System

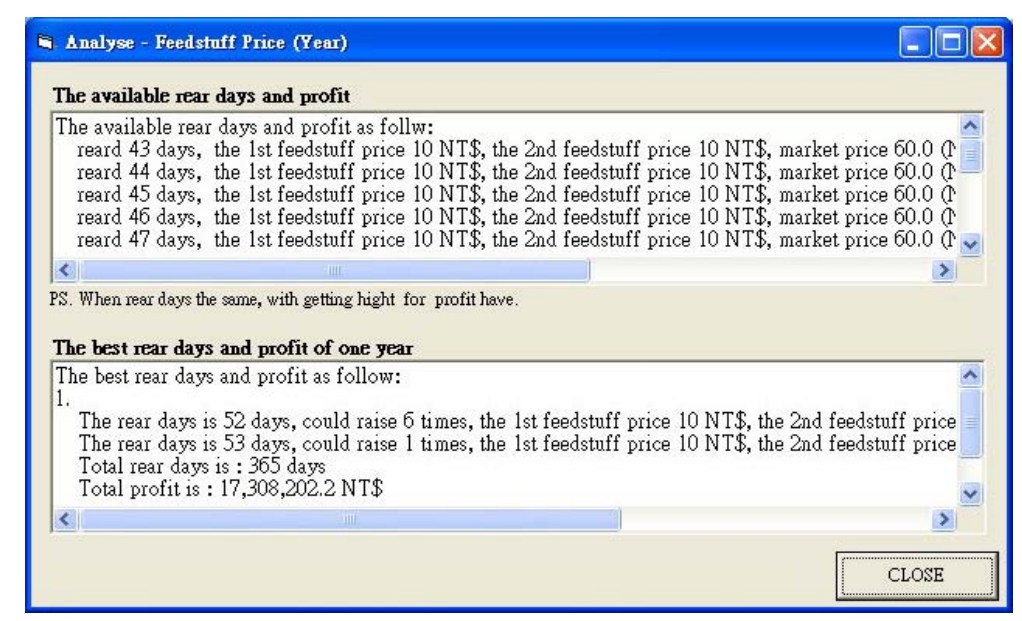

Fig. 11: The analysis results page for the POMA-BROILER System

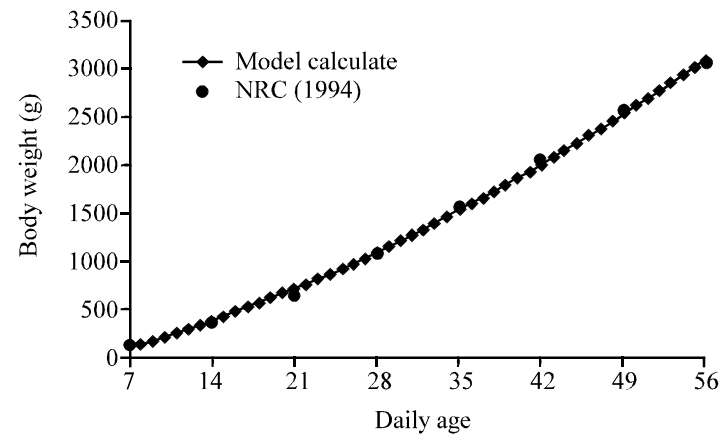

Fig. 12: Comparison of body weight between the model and the NRC (1994) recommendations

obtained by Pestana (1972) appear to indicate that there is no fixed optimum market age. The minimum cost of meat production varied as a function of several factors,

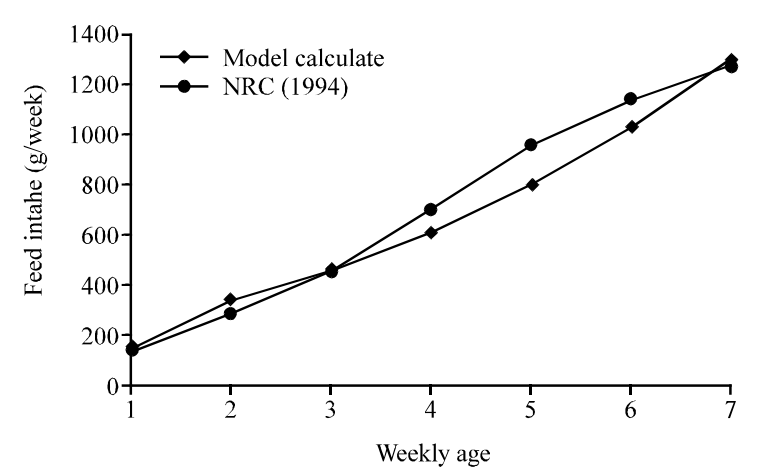

Fig. 13: Comparison of feed intake between the model and the NRC (1994)

especially in relation to the feed price and the growth rate. Sarma et al. (1986) reported that economic factors 
determine the optimal market age of Khaki Campbell ducks. Nakamura et al. (1988) used diets with different protein and ME values to find the optimal market age of broiler chickens. Lee et al. (1997) reported the optimal market age for Taiwan country chickens in a study performed during the hot and cool seasons to test growth curves, feed efficiency, changes in carcass parts and production costs. All of these studies used different methodologies to identify the optimal market age for poultry production.

Because of broiler growth rates and the use of an Automatic Slaughter System, the carcass size of broilers is increasingly important. It appears to be more profitable to market broilers at an optimal age to meet consumer requirements and obtain an acceptable market weight. Thus if the optimal market age of broilers can be predicted, producers can increase the profits from their production. Because very few researchers have attempted to study the optimal market age of broilers from an economic viewpoint, the aim of this study was to design a Simulation Model to predict the optimal market age of broilers with the intention of increasing profit for farmers.

\section{CONCLUSION}

In this study, the demonstration shows that this simulation model is a useful tool for the future production of broilers. Using the model, managers can calculate the optimal market age and analyse the maximum profit decision using different combinations of feed, costs, growth function, FCR function and acceptable market weight. This simulation model provides a consultation tool for adjusting farm production and management to achieve maximum profits.

\section{ACKNOWLEDGEMENT}

The researchers wish to acknowledge the Council of Agriculture in Taiwan for financial support of this research (93AS-1 .5.1-LI-L1).

\section{REFERENCES}

Ahmad, H.A., 2009. Poultry growth modeling using neural networks and stimulated data. J. Applied Poult. Res., 18: 440-446.

Burlacu, G., R. Burlacu, I. Columbeanu and G. Alexandru, 1990. Mathematical model for energy and protein balance simulation in broilers. Arch. Anim. Nutr., 40: 409-422.

COA, 2010. Taiwan Agricultural Yearbook. Council of Agriculture, Taipei, Taiwan.
Emmans, G.C., 1981a. A Model of the Growth and Feed Intake of ad-libitum fed Animals, Particularly Poultry. In: Computers in Animal Production, Hillyer, G.M., C.T. Whittemore and R.G. Gunn (Eds.). BSAP, USA., Pages: 155.

Emmans, G.C., 1981b. Computer simulation in poultry production. Proceedings of the 3rd European Symposium on Poultry Nutrition, October 26-29, 1981, Peebles, Scotland, UK.

Emmans, G.C., 1995. Problems in modelling the growth of poultry. Worlds Poult. Sci. J., 51: 77-89.

Farooq, M., M.A. Mian and A. Asghar, 2001. Factors affecting cost of production and net profit per broiler in the subtropics. Livestock Res. Rural Dev.

Grosskopf, K. and E. Matthaus, 1990. Mathematical simulation of the broiler production process. Syst. Anal. Modell. Simul., 7: 473-491.

Hu, C.L., 1995. Study on the growth curve of broiler carcass. M.Sc. Thesis, National Chung Hsing University, Taichung, Taiwan.

Lee, Y.P., P.L. Chiang and H.H. Huang, 1997. A study on the optimal marketing age of Taiwan Country chicken. J. Chin. Soc. Anim. Sci., 26: 285-296.

Leeson, S. and J.D. Summers, 1980. Production and carcass characteristics of the broiler chicken. Poult. Sci., 59: 786-798.

Muramatsu, T. and S. Isariyodom, 1989. Computersimulated growth prediction of replacement pullets with special reference to seasonal changes in feed intake. Poult. Sci., 68: 771-780.

NRC, 1994. Nutrient Requirements of Poultry. 9th Edn., National Academy Press, Washington, DC., USA., ISBN: 9780309048927 , Pages: 155.

Nakamura, K., S. Tokumitsu and H. Tokunaga, 1988. Effect of diets with different protein and metabolizable energy values on the optimum market age of the broiler chicken. Jpn. J. Poult. Sci., 25: 319-329.

Pestana, A.G., 1972. Study of some of the technical factors influencing the production costs for one kilo of poultry meat. III. Influence of the weight and age of the chicken at slaughter and the contract system used. J. Anim. Nutr., 10: 177-198.

Roan, S.W. and B.Y. Wang, 1996. Computer simulation model of broiler growth. J. Chin. Soc. Anim. Sci., 25: 75-96.

Roan, S.W. and C.L. Hu, 1996. Effect of dietary energy content on broiler carcass characteristics. J. Agric. For., 45: 49-62. 
Roan, S.W., 1991. Bio-economic models for the simulation of the production and management of the growing pigs and sows. Ph.D. Thesis, University of Edinburgh, UK.

Roush, W.B., W.A. Dozier and S.L. Branton, 2006. Comparison of gomertz and neural network models of broiler growth. Poult. Sci., 85: 794-797.

Sarma, N.F., K.K. Baruah and N.N. Bora, 1986. Optimum market age of khaki campbell for meat production. Idn. J. Poult. Sci., 21: 296-299.

Supaporn, I., I. Tasaki and J. Okumura, 1988. Construction of a mathematical model for predicting broiler performance. Jpn. J. Poult. Sci., 25: 191-200.

Talpaz, H., J.R. De La Torre, P.J.H. Sharpe and S. Hurwitz, 1986. Dynamic optimization model for feeding of broilers. Agric. Syst., 20: 121-132.

Velu, J.G., D.H. Baker and H.M. Scott, 1972. Regression equations for determining body composition of young chicks. Poult. Sci., 51: 698-699.
Wang, B.Y., S.W. Roan and J.C. Hsu, 1995. A model to predict feed intake of broilers. J. Taiwan Livest. Res., 28: 269-283.

Wolynetz, M.S. and I.R. Sibbald, 1986a. Prediction of major body components of broiler chicks from a small subset. Poult. Sci., 65: 2167-2172.

Wolynetz, M.S. and I.R. Sibbald, 1986b. Prediction of major body components of broiler chicks. Poult. Sci., 65: 2173-2185.

Wolynetz, M.S. and I.R. Sibbald, 1986c. Relationships among major body components of broiler chicks. Poult. Sci., 65: 2324-2329.

Wolynetz, M.S. and I.R. Sibbald, 1990. Estimates of body components in broiler chickens from body weight and dry matter. Poult. Sci., 69: 1318-1324.

Zoons, J., J. Buyse and E. Decuypere, 1991. Mathematical models in broiler raising. World's Poult. Sci. J., 47: $243-255$. 